\title{
Properties of Recycled Aggregate Concrete Reinforced with Polypropylene Fibre
}

\author{
Wan Nur Syazwani Wan Mohammad ${ }^{1}$, Sallehan Ismail ${ }^{2}$ and Wan Abdullah Wan Alwi ${ }^{3}$ \\ 1, 2, 3 Building Department, Faculty Architecture Planning and Surveying, UiTM Seri Iskandar Campus, UiTM Perak Darul Ridzuan
}

\begin{abstract}
This research work is aimed to investigate how the addition of various proportion of polypropylene fibre affects the mechanical strength and permeability characteristics of recycled aggregate concrete (RAC) which has been produced with treated coarse recycled concrete aggregate (RCA). Further research on RAC properties and their applications is of great importance as the scarcity of virgin aggregate sources in close proximity to major urban centers is becoming a worldwide problem. In this study, the hardened RAC properties at the curing age of 7 and 28 days such as compressive strength, flexural strength, ultrasonic pulse velocity (UPV), water absorption and total porosity were evaluated and compare with control specimens. Experimental result indicates that although the inclusion of the treated coarse RCA can enhance the mechanical strength and permeability properties of RAC, Further modification by addition of polypropylene fibre can optimize the results.
\end{abstract}

Keyword: Mechanical strength, permeability, Polypropylene fibre, recycled aggregate concrete, treated coarse RCA

\section{Introduction}

The recycling of concrete waste into recycled concrete aggregates (RCA) has been identified as a potential source of construction aggregates. Previous studies have highlighted the benefits of large-scale recycling of concrete waste: its great potential benefits in controlling the over-discharge of construction and demolition wastes that otherwise would have been disposed in landfills, decreases the dependence of the construction industry on natural aggregates, thereby preserving natural resources, provides savings from the treatment of waste disposal, and yields alternative sources for urban areas facing shortage of natural aggregates [1-3].

However, technical problems are encountered when using the RCA obtained from crushing concrete waste. The physical and mechanical properties of RCA are remarkably different from that of natural aggregates. RCA is composed of natural aggregates and a specific amount of adhered mortar that surrounds the original aggregate particles. Generally the RCA compose of $65 \%$ to $70 \%$ natural aggregates is surrounded by $30 \%$ to $35 \%$ adhered mortar [4]. The presence of the adhering mortars to recycled aggregate is the main reason for lower quality compared with natural aggregates because the adhered mortar is characterised as porous $[5,6]$ and presents numerous microcracks[6]. As a result, RCA properties are characterised by lower density, higher water absorption capacity, and lower strength compared with the natural aggregate $[5,7,8]$. Consequently, when using RCA in the production of new concrete, these characteristics of the aggregate may have adverse effect on the fresh and the hardened properties of concrete. A comparison of the properties of recycled aggregate concrete (RAC) and normal concrete (natural aggregate), as reported by several studies is shown in Table 1 .

Table 1: The properties of recycled aggregate concrete compared with normal concrete

\begin{tabular}{|c|c|c|}
\hline $\begin{array}{l}\text { RAC } \\
\text { Properties }\end{array}$ & $\begin{array}{l}\text { Comparison } \\
\text { RAC with } \\
\text { Normal } \\
\text { Concrete }\end{array}$ & References \\
\hline Workability & $\begin{array}{l}\text { Increased } \\
\text { slump loss }\end{array}$ & $\begin{array}{l}\text { Chakradhara } \\
\text { Rao, et al. [7], } \\
\text { Poon, Shui, } \\
\text { Lam, et al. [9] }\end{array}$ \\
\hline $\begin{array}{l}\text { Compressive } \\
\text { strength }\end{array}$ & $\begin{array}{l}\text { Decreased up } \\
\text { to } 20 \%\end{array}$ & $\begin{array}{l}\text { Poon, et al., } \\
\text { [9], Kou, } \\
\text { Poon, \& Chan } \\
\text { [10], Yang, } \\
\text { Hao, \& Wang } \\
{[1]}\end{array}$ \\
\hline $\begin{array}{l}\text { Splitting and } \\
\text { flexural } \\
\text { tensile } \\
\text { strength }\end{array}$ & \begin{tabular}{l}
\multicolumn{2}{l}{ Decreased } \\
more than \\
$10 \%$
\end{tabular} & $\begin{array}{l}\text { Gómez- } \\
\text { Soberón [11], } \\
\text { Rao, et al. } \\
\text { [12], Tabsh \& } \\
\text { Abdelfatah [8] }\end{array}$ \\
\hline $\begin{array}{l}\text { Modulus of } \\
\text { elasticity }\end{array}$ & \begin{tabular}{l}
\multicolumn{2}{l}{ Decreased } \\
more than \\
$20 \%$
\end{tabular} & $\begin{array}{l}\text { Kou, et al. } \\
{[10],} \\
\text { Tangchirapat, } \\
\text { Buranasing, \& } \\
\text { Jaturapitakkul } \\
\text { [13] }\end{array}$ \\
\hline
\end{tabular}




\begin{tabular}{|l|l|l|}
\hline $\begin{array}{l}\text { Drying } \\
\text { shrinkage }\end{array}$ & $\begin{array}{l}\text { Increased } \\
\text { more than } \\
30 \%\end{array}$ & $\begin{array}{l}\text { Gómez- } \\
\text { Soberón [11], } \\
\text { Kishore \& } \\
\text { Bairagi [14] }\end{array}$ \\
\hline $\begin{array}{l}\text { Water } \\
\text { absorption }\end{array}$ & $\begin{array}{l}\text { Increased up } \\
\text { to 40\% }\end{array}$ & $\begin{array}{l}\text { Grdic, } \\
\text { Toplicic- } \\
\text { Curcic, } \\
\text { Despotovic, \& } \\
\text { Ristic [15], } \\
\text { Gomes \& de } \\
\text { Brito [16] }\end{array}$ \\
\hline $\begin{array}{l}\text { Chloride } \\
\text { penetration }\end{array}$ & $\begin{array}{l}\text { Increased or } \\
\text { low resistance }\end{array}$ & $\begin{array}{l}\text { Ann, Moon, } \\
\text { Kim, \&you } \\
\text { [17] } \\
\text { Evangelista \& } \\
\text { de Brito [18] } \\
\text { Otsuki, et al. } \\
\text { [19] }\end{array}$ \\
\hline
\end{tabular}

The poor qualities of recycled aggregate, which crucially affect the performance of concrete, have become a challenge, and the issues have limited the widespread commercial use of recycled aggregate in concrete production. Hence in realizing the widespread commercial use of RAC in the construction industry, particularly in structural application, the adverse effects related to the inherent low quality of RCA must be minimized. Previous research as demonstrated by the authors[20]has proposed surface treatment methods that have the potential to minimize the adverse effects of RCA. In this work the surface of coarse RCA was modified by coating it with wollastonite (calcium metasilicate) particles before incorporating it into the RAC mix. These works have proven that the effect of this treatment can improve the interfacial bonds between RCA and the new cement paste in the new concrete, thereby improving the concrete performance. However, focusing only on improving RCA properties through surface treatments without considering any existing residual mortar when producing new concrete is consider insufficient. The findings revealed that the effect of surface treatment method may affect the improvement of RAC properties up to a certain level only whereby the effect of surface treatment is mostly beneficial for strengthening of the interface bond between aggregate-new mortar compared with that of the aggregate-old adhered mortar bond. The presence of adhered mortar on RCA can cause the $\mathrm{RAC}$ to become a brittle and heterogeneous material characteristic than that of normal concrete.

Therefore this study is carried out in purpose to further extent from our previous works[20]. Accordingly, apart from the steps that improve RCA quality through surface treatment, observations also provide insight into the benefits of using fibre reinforcement systems in enhancing the properties of RAC. As reported from previous studies when randomly dispersed, the form of short discrete fibres are added to the concrete matrix, the texture is strengthened, and the brittleness of the concrete decreases[21]. The addition of fibres in concrete can increase the cracking resistance because the fibre bridges the gap between adjacent surfaces of existing microcracks, delays crack formation, and limits crack propagation[22].In addition, the well dispersion of fibre improving the internal structure of concrete thus enhancing the durability of concrete $[23,24]$. Hence the present experimental investigation aims to study the effects of using polypropylene fibre at various volume fractions on the mechanical and permeability properties of RAC which contain treated coarse RCA. The modified RAC specimens consist of treated coarse RCA and respective fibre at various content specimens are tested for compressive strength, flexural strength, and ultrasonic pulse velocity. Besides, the assessment on permeability of modified RAC involves the measurement of water absorption and total porosity test. The results are compared with the normal RAC (unmodified) which acts as control specimens. With the appropriate interpretation of the obtained results, it is possible to determine the most suitable and optimum fiber percentage that contribute to great enhancement in performance of modified RAC produce.

\section{Experimental program}

\subsection{Materials}

\section{Cement}

The cement used in the concrete mixtures in this study was ordinary Portland Cement Type I with a specific surface area of $1.0432 \mathrm{~m}^{2} / \mathrm{g}$ and a specific gravity of 3.02 . In this study, all the coarse aggregates used had a maximum size of $20 \mathrm{~mm}$.

\section{Coarse aggregate}

The natural coarse aggregates used were crushed granite. The coarse RCA used were generated from waste concrete cubes collected from the debris area. Jaw crushers were used to crush and to break down the concrete waste into smaller particle sizes. After crushing, the RCAs were graded to the required particle sizes using a vibrator sieve to obtain aggregates with the maximum sizes of $20 \mathrm{~mm}$. Table 2 show the sieve analysis of coarse aggregates that were used in this study. As mentioned before, this study will involve the use of treated coarse RCA. The preparation treatment for coarse RCA began by impregnating these materials in wollastonite solution for ascertain period and this is followed by draining and drying of that particle in the oven. The purpose of this step is to coat the surface of coarse RCA with wollastonite particles to refill the pores 
and cracks throughout its physical surface. The details on the materials and procedures involved for in carrying this treatment process are followed according to the previous research works done by the authors [20]. The comparison on the physical properties of the coarse natural aggregate (granite), coarse treated and untreated RCA by analyzing them in terms particle density, water absorption and mechanical strength is shown in Table 3.

Table 2: Sieve analysis of the fine and coarse aggregates

\begin{tabular}{|l|l|l|l|l|l|l|l|l|l|}
\hline \multirow{2}{*}{ Agg. } & \multicolumn{7}{|c|}{ Aggregate passing (\%) according to sieve size (mm) } \\
\cline { 2 - 10 } & $\begin{array}{l}0.1 \\
5\end{array}$ & 0.3 & 0.6 & 1.18 & 2.36 & 5 & 10 & 14 & 20 \\
\hline Fine & 0.9 & 8.8 & $\begin{array}{l}22 . \\
7\end{array}$ & 45.3 & 77.4 & 100 & 100 & $\begin{array}{l}10 \\
0\end{array}$ & $\begin{array}{l}10 \\
0\end{array}$ \\
\hline $\begin{array}{l}\text { Coarse } \\
\text { Natural }\end{array}$ & 0.0 & 0.0 & 0.0 & 0.0 & 0.2 & 0.2 & 31 & $\begin{array}{l}59 \\
.2\end{array}$ & $\begin{array}{l}10 \\
0\end{array}$ \\
\hline $\begin{array}{l}\text { Coarse } \\
\text { RCA }\end{array}$ & 0.0 & 0.0 & 0.0 & 0.0 & 0.4 & 0.8 & 30 & $\begin{array}{l}60 \\
.4\end{array}$ & $\begin{array}{l}10 \\
0\end{array}$ \\
\hline
\end{tabular}

Table 3: Properties of the coarse aggregate

\begin{tabular}{|l|l|l|l|l|}
\hline $\begin{array}{l}\text { Properties } \\
\text { of } \\
\text { Aggregate }\end{array}$ & $\begin{array}{l}\text { Sizes of } \\
\text { aggregate }\end{array}$ & $\begin{array}{l}\text { Natural } \\
\text { Granite }\end{array}$ & $\begin{array}{l}\text { Un- } \\
\text { treated } \\
\text { RCA }\end{array}$ & $\begin{array}{l}\text { Treate } \\
\text { d RCA }\end{array}$ \\
\hline $\begin{array}{l}\text { Particle } \\
\text { Density - } \\
\text { Oven Dry } \\
\left(\mathrm{Mg} / \mathrm{m}^{3}\right)\end{array}$ & $20 \mathrm{~mm}$ & 2.60 & 2.33 & 2.4 \\
\hline & $10 \mathrm{~mm}$ & 2.58 & 2.23 & 2.3 \\
\hline $\begin{array}{l}\text { Water } \\
\text { absorption } \\
(\%)\end{array}$ & $20 \mathrm{~mm}$ & 0.60 & 4.44 & 3.71 \\
\hline & $10 \mathrm{~mm}$ & 0.70 & 5.58 & 5.02 \\
\hline $\begin{array}{l}\text { Agg. } \\
\text { crushing } \\
\text { value (\%) }\end{array}$ & $14 \mathrm{~mm}$ & 24.32 & 29.15 & \\
\hline $\begin{array}{l}\text { Agg. } \\
\text { impact } \\
\text { value (\%) }\end{array}$ & $14 \mathrm{~mm}$ & 13.98 & 21.78 & \\
\hline $\begin{array}{l}\text { LA } \\
\text { abrasion } \\
\text { value (\%) }\end{array}$ & $14 \mathrm{~mm}$ & 34.76 & 39.12 & \\
\hline
\end{tabular}

\section{Fine aggregate}

The natural fine aggregate or sand used in this study consisted of particles that passed through a sieve size of $5.00 \mathrm{~mm}$ and were mainly $75 \mu \mathrm{m}$ in size. The fine aggregate used was uncrushed quartzite natural river sand. Table 2 shows the sieve analysis of the fine and coarse aggregates that were used in this study, which were graded according to BS 812- Part 103.1.

\section{Superplasticizer}

Superplasticizer (SP) based on sulphonated naphthalene polymers were used to enhance the workability of the concrete.

\section{Fibre}

Polypropylene (PP) fibres produced in fibrillated form, was supplied by Timuran Engineering Sdn. Bhd. (Figure 1). The fibrillated polypropylene form of this fiber opens linked fibers and separates into multistrand or individual filaments in the concrete during mixing. The different properties and specifications of the polypropylene fibres are shown in Table 4.

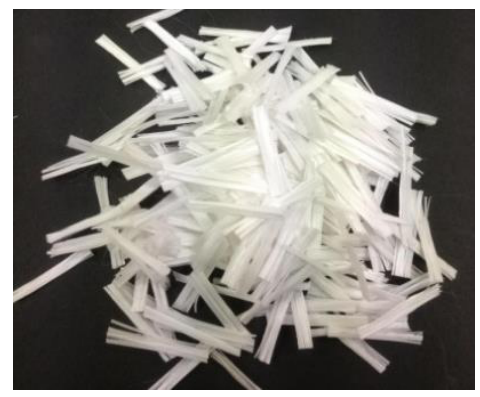

Figure 1: Fibrillated polypropylene fibre

Table 4: Specification of polypropylene fibres

\begin{tabular}{|l|l|}
\hline Item & Specifications of fibre \\
\hline Average Length & $15 \mathrm{~mm}$ \\
Tensile Strength & $45-60 \mathrm{ksi}$ \\
Specific Gravity & $0.9 \mathrm{~g} / \mathrm{cm}^{3}$ \\
Youngs Modulus & $0.5 \times 10 \mathrm{ksi}$ \\
Melting Point & $160^{\circ} \mathrm{C}-170^{\circ} \mathrm{C}$ \\
Ignition Point & $590^{\circ} \mathrm{C}$ \\
\hline
\end{tabular}

\section{Mix Design}

The mix design of concrete followed the British Method [25], which is prepared based on constant effective water/cement ratio of 0.41 for all concrete mixtures to achieve targeted compressive strength of $50 \mathrm{MPa}$ at the 28th day. The mixture proportions of the base matrix for all specimens are given in Table 5. It is noticed that the dosage compositions of the coarse aggregates in all RAC mix were designed by replacing the natural coarse aggregate with untreated and treated RCA at $60 \%$ weight of the total coarse aggregate content. One batch of mixtures was prepared with untreated RCA and served as the sample for comparison purposes. While the rests are in types of modified RAC which consist of treated coarse RCA and cast with and without fibres. The detailed description of material composition and 
various percentages of respective fibres used in the different RAC mixes are tabulated in the Table 6 . Considering the loss of water caused by the absorption of the aggregates and the effect of fibre addition during mixing, a superplasticizer was added in the concrete mix at the dosage of $0.2-0.3 \%$ by the cement weight to maintain the slump of the concrete mix.

Table 5: Mix proportion

\begin{tabular}{ll}
\hline Constituents & Proportion $\left(\mathbf{k g} / \mathbf{m}^{\mathbf{3}}\right)$ \\
\hline Water & 210 \\
Cement & 512 \\
Sand & 722 \\
Coarse Aggregate & \\
Granite & 382 \\
RCA & 574 \\
\hline
\end{tabular}

Table 6: Detailed descriptions of all RAC mixes

\begin{tabular}{|c|c|c|c|c|}
\hline \multirow{2}{*}{ Mix } & \multirow{2}{*}{$\begin{array}{l}\text { Types of } \\
\text { mix }\end{array}$} & \multicolumn{2}{|c|}{$\begin{array}{l}\text { Vol. dosage of } \\
\text { fibre }(\%)\end{array}$} & \multirow[t]{2}{*}{$\begin{array}{l}\text { SP } \\
(\%)\end{array}$} \\
\hline & & Polyolefin & PP & \\
\hline $\begin{array}{l}\mathrm{CO} \\
\text { (Control) }\end{array}$ & $\begin{array}{l}\text { Untreated } \\
\text { RCA }\end{array}$ & 0 & 0 & 0 \\
\hline TR & $\begin{array}{l}\text { Treated } \\
\text { RCA }\end{array}$ & 0 & 0 & 0.2 \\
\hline PP03 & \multirow{5}{*}{$\begin{array}{l}\text { Treated } \\
\text { RCA + } \\
\text { Polypropy } \\
\text { lene fibre }\end{array}$} & 0 & 0.3 & 0.2 \\
\hline PP06 & & 0 & 0.6 & 0.2 \\
\hline PP09 & & 0 & 0.9 & 0.3 \\
\hline PP12 & & 0 & 1.2 & 0.3 \\
\hline PP15 & & 0 & 1.5 & 0.3 \\
\hline
\end{tabular}

\subsection{Mixing and Curing the Concrete Mixtures}

All concrete mixes in the study were prepared following the procedure prescribed in BS1881125.A drum mixer was used to prepare all the concrete mixes. All the concrete specimens were cast under laboratory conditions, demoulded at $24 \mathrm{~h}$ after casting, and then fully submerged in water at $(25 \pm 2)^{\circ} \mathrm{C}$ until further testing.

\subsection{Tests}

The compressive strength test was conducted in compliance with BS EN 12390-3 on $100 \mathrm{~mm}$ concrete cubes under uniaxial compression using an ELE International compression testing machine with the maximum capacity of $3000 \mathrm{kN}$. Flexural strength test was conducted to measure the ability of a concrete beam to resist bending. This test involved the fabrication with fabrication of the prism specimens with dimensions of $100 \times 100 \times 500 \mathrm{~mm}$ and the test procedures were performed in accordance to BS EN 12390-5. Ultrasonic pulse velocity (UPV) test is a non-destructive method to measure the speed of ultrasonic pulse passing through the materials. This test is applicable for predicting the concrete strength or distinguishing the presence of internal flaws, such as voids and cracks. The UPV test in this study was conducted in accordance with BS 1881-203 on prism specimen. Water absorption test was conducted in accordance with procedures prescribed in BS 1881-122 and the porosity of the concrete was determined using the vacuum saturation method developed by RILEM [26]. The entire tests programs were conducted on respective specimens at the ages of 7 and 28 days.

\section{Results and discussion}

\subsection{Compressive Strength}

The overall compressive strength results of all the tested specimens at the testing age of 7 and 28 days are illustrated in Figure 2. Generally, the results obtained from this investigation show that, the compressive strength of all the concrete specimens has a similar trend whereby their compressive strength increases over the curing period regardless of the types of mix composition. The result shows that the inclusion of $60 \%$ untreated RCA to replace the coarse natural aggregate noticeably affects the compressive strength of the RAC. This is clearly shown by the control (CO) RAC specimens in which their compressive strength at 28 days was achieved below the mix design strength target of $50 \mathrm{MPa}$. By contrast, the RAC prepared with the treated RCA likely performs better than that control specimens. However, the results suggest that the development in the compressive strength of RAC that contains the treated coarse RCA can be enhanced by adding certain volume fraction of fibers. Tables 7 shows that the inclusion of RAC mix with polypropylene fibre at the volume fraction of 0.3 to $1.2 \%$ has resulted in an increase in the compressive strength of RAC in the variation range of 11 up to $23 \%$ at the age of 28 days. From the results it is noticed that the RAC mix which contains polypropylene fiber at $0.6 \%$ demonstrated the highest compressive strength at the age of 28 days compared with others specimens. This improvement contributes to the possible function of randomly oriented fibers to assist in controlling the propagation of crack growth and limiting the crack width in the cement matrix [22, 27]. 


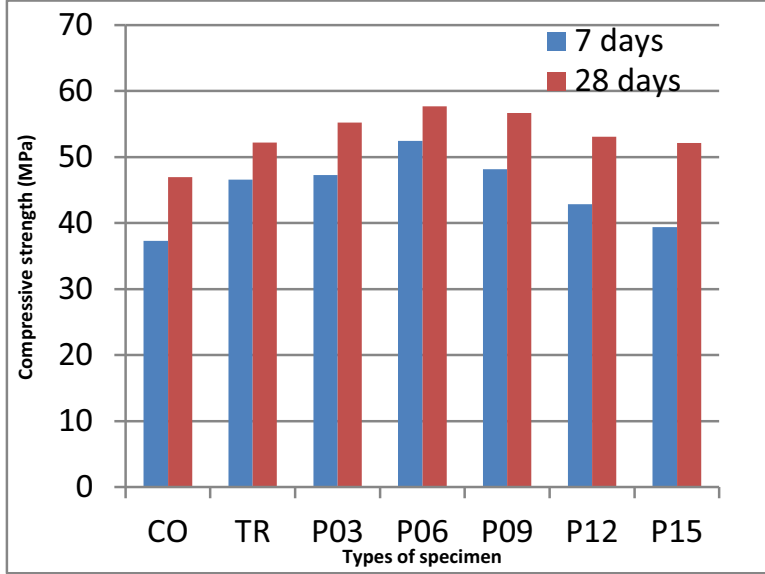

Figure 2: Compressive strength of tested specimens at various curing age

Table 7: Compressive strength relative to the $\mathrm{CO}$ specimen

\begin{tabular}{|l|l|l|}
\hline \multirow{2}{*}{ Specimens } & \multicolumn{2}{|l|}{ Curing age } \\
\cline { 2 - 3 } & $\mathbf{7}$ days & $\mathbf{2 8}$ days \\
\hline CO & 1.00 & 1.00 \\
\hline TR & 1.25 & 1.11 \\
\hline P03 & 1.27 & 1.18 \\
\hline P06 & 1.41 & 1.23 \\
\hline P09 & 1.29 & 1.21 \\
\hline P12 & 1.15 & 1.13 \\
\hline P15 & 1.06 & 1.11 \\
\hline
\end{tabular}

\subsection{Flexural strength}

The flexural strength of the overall specimens across the curing age is illustrated in Figures 3 and Table 8 presents the relative flexural strength of the all mixes (expressed as a percentage of that corresponding to the RO specimens) for the entire testing period .Analysis on the average flexural strength results of specimens indicates that the flexural strength of the RAC which contains the treated RCA (TR) seems to be comparable with the untreated RCA (CO) at the entire testing age. As shown in Table 8 , the flexural strength of the TR specimen is found to be $99 \%$ and $104 \%$, in correspondent to the $\mathrm{CO}$ specimen at the testing age of 7 and 28 days respectively. However, the profile gain in the flexural strength is remarkably improved for the specimens added by fibre. It is clearly shown in Table 8 that $\mathrm{P} 15$ has achieved the highest flexural strength result which is $14 \%$ higher compared to the control at the age of 28 days. This is followed by P06 and P09 where their gain in flexural strength is 3\% higher compared with the control for the testing age of 28 days. This result suggests that the randomly oriented polypropylene fibers effective in providing energy absorbing mechanism (bridging action) thus delaying crack propagationsunder flexural loading.

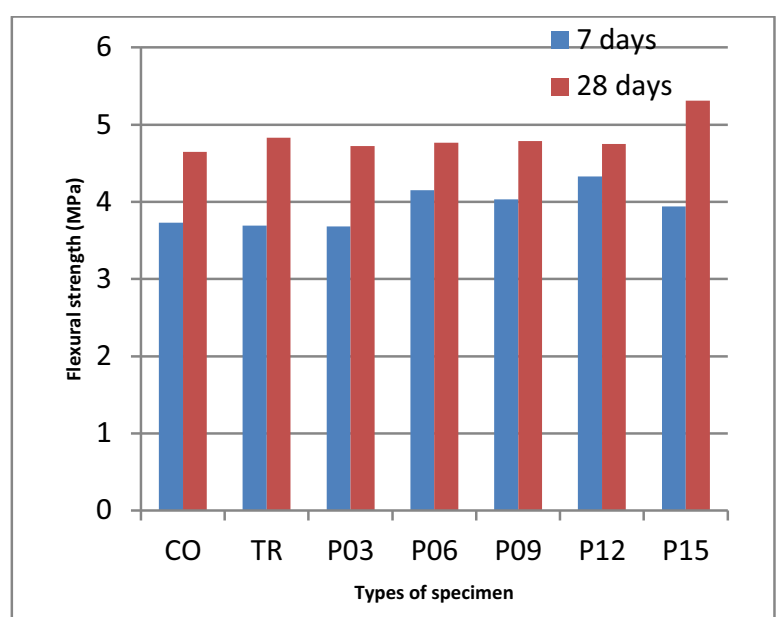

Figure 3: Flexural strength of tested specimens at various curing age

Table 8: Flexural strength relative to the $\mathrm{CO}$ specimen

\begin{tabular}{|l|l|l|}
\hline \multirow{2}{*}{ Specimens } & \multicolumn{2}{|l|}{ Curing age } \\
\cline { 2 - 3 } & $\mathbf{7}$ days & $\mathbf{2 8}$ days \\
\hline CO & 1.00 & 1.00 \\
\hline TR & 0.99 & 1.04 \\
\hline P03 & 0.99 & 1.02 \\
\hline P06 & 1.11 & 1.03 \\
\hline P09 & 1.08 & 1.03 \\
\hline P12 & 1.16 & 1.02 \\
\hline P15 & 1.06 & 1.14 \\
\hline
\end{tabular}

\subsection{Ultrasonic pulse velocity (UPV)}

The result generally shows that the UPV values of all the specimens increase with prolonged curing age (Figure 4). Among the RAC specimens, the CO demonstrated the lowest UPV values at the entire testing age. Contrast, all modified RAC presents the high UPV result with regard to the control particularly the specimens which are consisted of fibre. From the results, the highest UPV value at the age of 28 days is attained by the P06. In this study, an attempt is made to relate the UPV value with the compressive strength of all the specimens at their respective testing ages, as shown in Figure 5. The graph shows that the relationship between the UPV of all the tested specimens and compressive strength is linear and proportional, with the R-square values achieved at 0.815 . 


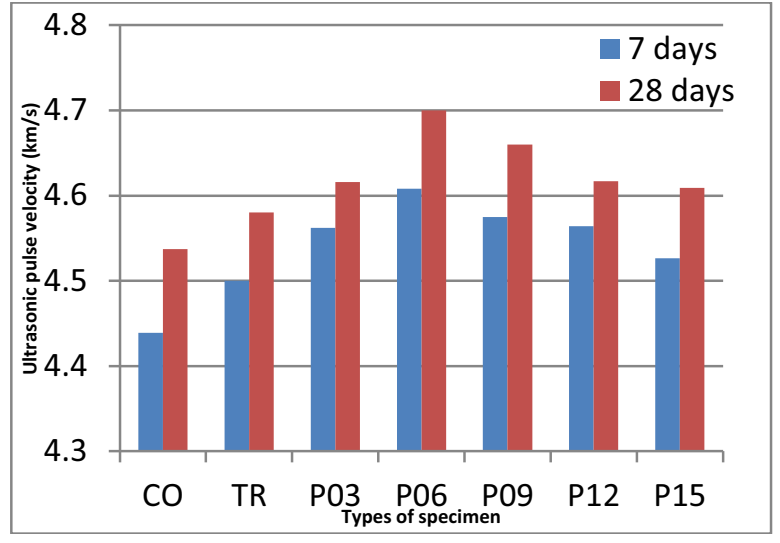

Figure 4: UPV value of tested specimens at various curing age

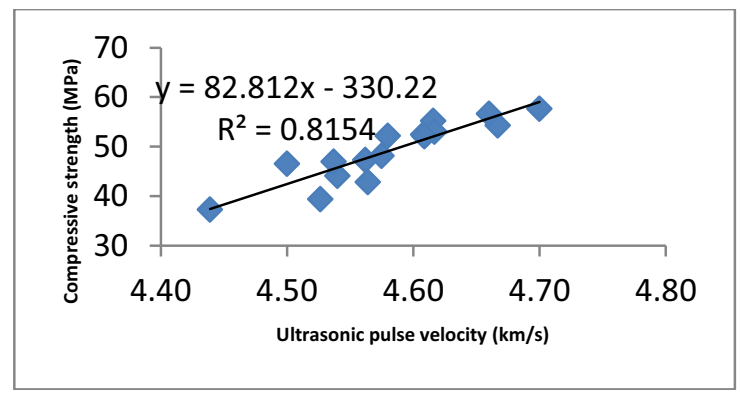

Figure 5: Relationship between compressive strength and UPV

\subsection{Water absorption}

The water absorption results of all the specimens relative to the age of the specimens are plotted in graph as shown in Figure 6.In general, the obtained water absorption rate of all specimens tends to decrease over the curing period because of the increasing rate of hydration of cement products that fills the capillary pores of the cement matrix. From the results it is observed that the water absorption rate of the $\mathrm{CO}$ specimens with the untreated RCA is relatively higher than that of the other specimens across all the testing ages. Such behavior might be due to the porous and high absorption characteristics of the untreated coarse RCA leading to a higher water absorption rate of the RAC. It is interesting to note that apart from this study demonstrated that apart from using the treated coarse RCA, the water absorption of the RAC is significantly reduced with the introduction of fibres. As shown in Table 9, the specimen of P09 achieved the lowest porosity rate which is $17 \%$ lower than that for the control specimen at 28 days. This improvement may be due to the non-water absorption characteristic of synthetic fibres. In addition, the distribution of fibres can modify the microstructure of hardened cement pastes in the to seal and bridge the capillary pore structure, which results in minimal void interconnection [28].

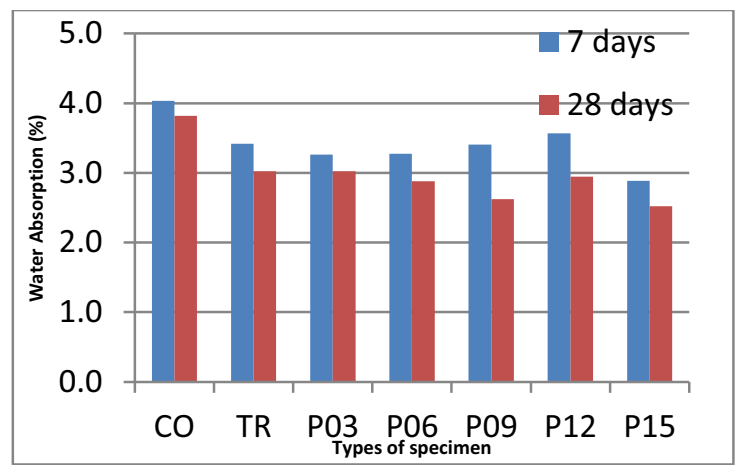

Figure 6: Water absorption of tested specimens at various curing age

Table 9: Water absorption relative to the $\mathrm{CO}$ specimen

\begin{tabular}{|l|l|l|}
\hline \multirow{2}{*}{ Specimens } & \multicolumn{2}{|l|}{ Curing age } \\
\cline { 2 - 3 } & $\mathbf{7}$ days & $\mathbf{2 8}$ days \\
\hline CO & 1.00 & 1.00 \\
\hline TR & 0.85 & 0.79 \\
\hline P03 & 0.81 & 0.79 \\
\hline P06 & 0.81 & 0.75 \\
\hline P09 & 0.85 & 0.69 \\
\hline P12 & 0.88 & 0.77 \\
\hline P15 & 0.72 & 0.66 \\
\hline
\end{tabular}

\subsection{Total porosity}

The porosity results of all the concrete specimens with respect testing age are presented in Figure 7. In general, the obtained total porosity rate of all concrete mixtures follows a similar trend as the rate gain of water absorption, where the gain in porosity values of all concrete mixtures gradually decreases with the increase in the curing period. For all the testing ages, the higher porosity rates were obtained from the $\mathrm{CO}$ specimens that produced high wateraccessible porosities compared with the other specimens. On the other hand the gain in the porosity rate of the modified RAC especially with the inclusion of fibres is remarkably lower than the control specimens in a prolonged curing period. Table 10 shows that after 28 days, the specimen of P09 presents the lowest porosity rate compared to the other specimens which are $17 \%$ lower when compared with the control. 


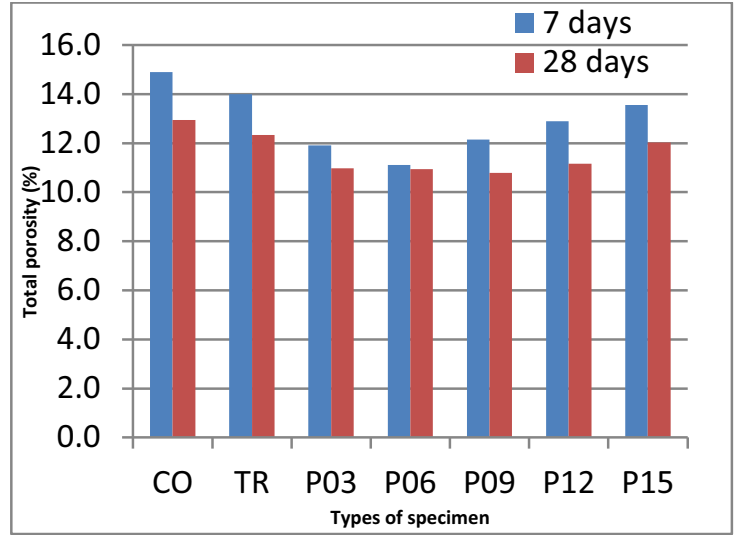

Figure 7: Total porosity of tested specimens at various curing age

Table 10: Total porosity relative to the CO specimen

\begin{tabular}{lll}
\hline & \multicolumn{2}{l}{ Curing age } \\
\cline { 2 - 3 } Specimens & 7 days & 28 days \\
\hline CO & 1.00 & 1.00 \\
TR & 0.94 & 0.95 \\
P03 & 0.80 & 0.85 \\
P06 & 0.75 & 0.85 \\
P09 & 0.81 & 0.83 \\
P12 & 0.87 & 0.86 \\
P15 & 0.91 & 0.93 \\
\hline \hline
\end{tabular}

\section{Conclusion}

The following conclusions could be drawn from the present investigation:-

The finding from this experimental study indicate that apart from the use of treated RCA effect, the inclusion of short discrete polypropylene fibres at different proportions can further enhance the mechanical strength of RAC. The results show that the maximum value of compressive strength is obtained when RAC specimens were added with polypropylene fibre at the $0.6 \%$ fibres content. The results also show the water absorption and total porosity characteristic of RAC is significantly reduced with the introduction of polypropylene fibres.

\section{References}

[1] Yang D-j, Hao Y-h, Wang T-c. Experimental Research on Recycled Aggregate Concrete for Highway Pavement. In: Heng W, Yinhai W, Jian R, Jiancheng $\mathrm{W}$, editors. Tenth International Conference of Chinese Transportation Professionals (ICCTP). Beijing, China: ASCE; 2010. p. 309.
[2] Kou SC, Poon CS, Agrela F. Comparisons of natural and recycled aggregate concretes prepared with the addition of different mineral admixtures. Cement and Concrete Composites. 2011;33(8):78895.

[3] Ismail S, Hoe KW, Ramli M. Sustainable Aggregates: The Potential and Challenge for Natural Resources Conservation. Procedia - Social and Behavioral Sciences. 2013;101(0):100-9.

[4] Poon CS, Shui ZH, Lam L. Effect of microstructure of ITZ on compressive strength of concrete prepared with recycled aggregates. Construction and Building Materials. 2004;18(6):461-8.

[5] Padmini AK, Ramamurthy K, Mathews MS. Influence of parent concrete on the properties of recycled aggregate concrete. Construction and Building Materials. 2009;23(2):829-36.

[6] Tam VWY, Gao XF, Tam CM. Microstructural analysis of recycled aggregate concrete produced from two-stage mixing approach. Cement and Concrete Research. 2005;35(6):1195-203.

[7] Chakradhara Rao M, Bhattacharyya S, Barai S. Influence of field recycled coarse aggregate on properties of concrete. Materials and Structures. 2011;44(1):205-20.

[8] Tabsh SW, Abdelfatah AS. Influence of recycled concrete aggregates on strength properties of concrete. Construction and Building Materials. 2009;23(2):1163-7.

[9] Poon CS, Shui ZH, Lam L, Fok H, Kou SC. Influence of moisture states of natural and recycled aggregates on the slump and compressive strength of concrete. Cement and Concrete Research. 2004;34(1):31-6.

[10] Kou SC, Poon CS, Chan D. Influence of Fly Ash as Cement Replacement on the Properties of Recycled Aggregate Concrete. Journal of Materials in Civil Engineering. 2007;19(9):709-17.

[11] Gómez-Soberón JMV. Porosity of recycled concrete with substitution of recycled concrete aggregate: An experimental study. Cement and Concrete Research. 2002;32(8):1301-11.

[12] Rao A, Jha KN, Misra S. Use of aggregates from recycled construction and demolition waste in concrete. Resources, Conservation and Recycling. 2007;50(1):71-81.

[13] Tangchirapat W, Buranasing R, Jaturapitakkul C. Use of High Fineness of Fly Ash to Improve Properties of Recycled Aggregate Concrete. Journal of Materials in Civil Engineering. 2010;22(6):56571.

[14] Kishore R, Bairagi NK. Creep and drying shrinkage of recycled aggregate concrete. In: Made AM, Sabnis G, Tan JSY, editors. The First International Conference on Recent Advances in Concrete Technology Washington, DC: Destech Pubns Inc 2007. p. 289-98.

[15] Grdic ZJ, Toplicic-Curcic GA, Despotovic IM, Ristic NS. Properties of self-compacting concrete 
prepared with coarse recycled concrete aggregate. Construction and Building Materials. 2010;24(7):1129-33.

[16] Gomes M, de Brito J. Structural concrete with incorporation of coarse recycled concrete and ceramic aggregates: durability performance. Materials and Structures. 2009;42(5):663-75.

[17] Ann KY, Moon HY, Kim YB, Ryou J. Durability of recycled aggregate concrete using pozzolanic materials. Waste Management. 2008;28(6):993-9.

[18] Evangelista L, de Brito J. Durability performance of concrete made with fine recycled concrete aggregates. Cement and Concrete Composites. 2010;32(1):9-14.

[19] Otsuki N, Miyazato S-i, Yodsudjai W. Influence of Recycled Aggregate on Interfacial Transition Zone, Strength, Chloride Penetration and Carbonation of Concrete. Journal of Materials in Civil Engineering. 2003;15(5):443-51.

[20] Ismail S, Ramli M. Effect of Different Moisture States of Surface-Treated Recycled Concrete Aggregate on Properties of Fresh and Hardened Concrete. International Journal of Civil, Architectural, Structural and Construction Engineering 2014;8(1):65-71.

[21] Maruthachalam D., Muthukumar J. Flexural behaviour of hybrid fibre reinforced concrete beams: a general review. Indian Journal of Engineering. 2013;2(3):14-6.

[22] Şahin Y, Köksal F. The influences of matrix and steel fibre tensile strengths on the fracture energy of high-strength concrete. Construction and Building Materials. 2011;25(4):1801-6.

[23] Peled A, Jones J, Shah SP. Effect of matrix modification on durability of glass fiber reinforced cement composites. Materials and Structures 2005;38:163-71.

[24] Corinaldesi V, Moriconi G. Durable fiber reinforced self-compacting concrete. Cement and Concrete Research 2004;34:249-54.

[25] Teychenné DC, Franklin RE, Erntroy HC, Hobbs DW, Marsh BK. Design of normal concrete mixes. Second ed. Watford, UK: Building Research Establishment; 1997.

[26] RILEM recommendations. Absorption of water by immersion under vacuum. Material Structure, RILEM CPC 113. 1984;101:393-4.

[27] Mesbah HA, Buyle-Bodin F. Efficiency of polypropylene and metallic fibres on control of shrinkage and cracking of recycled aggregate mortars. Construction and Building Materials. 1999;13(8):439-47.

[28] Poon CS, Qiao XC, Chan D. The cause and influence of self-cementing properties of fine recycled concrete aggregates on the properties of unbound sub-base. Waste Management. 2006;26(10):1166-72. 